\title{
THE MODERATING EFFECT OF DIVIDEND POLICY ON FREE CASH FLOW AND PROFITABILITY TOWARDS FIRM VALUE
}

\author{
G.A. Sri Oktaryani ${ }^{1}$ \\ Siti Sofiyah Abdul Mannan²
}

1Faculty of Economics and Business, University of Mataram, Email : oktaryani@gmail.com 2Faculty of Economics and Business, University of Mataram, Email : sofiyah_siti@ymail.com

\begin{tabular}{|c|c|}
\hline ARTICLE INFO & ABSTRACT \\
\hline $\begin{array}{l}\text { Keywords: } \\
\text { Dividend Policy, Free Cash Flow, } \\
\text { Profitability, Firm Value, Manufacture, } \\
\text { MRA } \\
\text { How to cite: } \\
\text { Oktaryani, Sri., Mannan, Siti Sofiyah } \\
\text { Abdul (2018). The moderating effect of } \\
\text { dividend policy on free cash flow and } \\
\text { profitability Towards firm value. JMM } \\
\text { UNRAM, 7(3), 1-12 } \\
\text { DOI: } \\
\text { 10.29303/jmm.v7i3.311 }\end{array}$ & $\begin{array}{l}\text { This study is aimed to determine the moderating effect } \\
\text { of Dividend Policy on Free Cash Flow and Profitability } \\
\text { towards Firm Value. This study use Moderate } \\
\text { Regression Analysis (MRA) as tool to analyze the } \\
\text { moderating effect of Dividend Policy on the sample } \\
\text { tested. Sample are chosen by using purposive } \\
\text { sampling method from all manufacture firms that } \\
\text { listed on Indonesian Stock Exchange throughout 2010- } \\
2015 \text { which offered cash dividend to their } \\
\text { shareholders. By using panel data, the findings show } \\
\text { that Free Cash Flow and Profitability themselves have } \\
\text { significant effect on Firm Value. But conversely, each } \\
\text { Free Cash Flow and Profitability does not have } \\
\text { significant effect on Firm Value after being moderated } \\
\text { by Dividend Policy. It is because the direct effect of } \\
\text { Free Cash Flow and Profitability toward Firm value is } \\
\text { bigger than the indirect effect. The results indicate that } \\
\text { Dividend Policy is just predictor moderation in this } \\
\text { case. } \\
\text { Comuright C } 2018 \text { IMM }\end{array}$ \\
\hline & Copyright $\odot 2018$ JMM UNRAM. All rights reserved. \\
\hline
\end{tabular}

\section{INTRODUCTION}

The main purpose of the establishment of the company is how to provide prosperity for the company's stakeholders. For companies that have been registered in the capital market, this effort can be done by increasing the value of the firm through increasing stock prices. The higher the stock price then the value of the firm will also increase. The increased firm value indirectly signals the investors that the firm's performance is predicted to be better in the 
future so it can encourage them to invest more in the company. Some factors that can provide positive signals in the improvement of firm value include corporate profitability, free cash flow, and dividends provided by the company.

Profitability of the firm is the ability of the company in obtaining profit to sales, total assets, and company's capital (Sartono, 2001). Profitability is important in its long-term survival effort, as it indicates whether the business entity has good prospects in the future or not. Research conducted by Chen and Chen (2011) proves that the profitability of the firm positively affects the value of the firm.

In addition to the firm's profitability factor, the quantity of free cash flow owned by the company can also affect the value of the firm. Jensen (1986) defines free cash flow as cash in excess of that required funding all positive net present value projects. Free cash flow temps managers to expand the scope of operations and the size of the firm, thus increasing managers' control and personal remuneration, by investing free resources in projects that have zero or negative net present values. High free cash flow indicates that the company is more flexible in investing so as to improve the firm's performance and ultimately affect the firm's value. This is supported by research conducted by Suartawan and Yasa (2016) who reported that free cash flow has a positive effect on the value of the firm. But the results of their study contradicted the results of research conducted by Mardasari (2012) which said that free cash flow can negatively affect the company. This is because high free cash flow can cause corporate managers to misuse the firm's cash flow for personal gain. According to Sindhu (2014), free cash flow is a sign of agency problems due to excess cash may not be returned to shareholders. When firms have free cash, any acquisitions are made by these firms are, by definition, negative net present value. The essence of the bird-in-the-hand theory of dividend policy is that shareholders are risk-averse and prefer to receive dividend payments rather than future capital gains.

High free cash flow can be utilized by managers to increase the company's investment or share it to shareholders in the form of dividends. According to Husnan and Pudjiastuti (2012), dividends are profits earned by the company and available to shareholders. There are times when the dividends are not shared by the company because the company feels the need to reinvest the profits. The amount of dividend distributed can affect the stock price. If the dividends are distributed high then the stock price will also increase, so the value of the firm is also high. Conversely, if the dividend is small then the share price of the company that distributes it is also low (Harjito and Martono, 2005). Dividends distributed to shareholders rely on company's policy. If the company uses a cash dividend policy then the cash spent for dividend payout is the outflow cash.

Based on the above explanation, it can be seen that the size of the dividend or cash dividend payment can affect the amount of free cash flow and the profitability of the firm. This certainly can ultimately affect the value of the firm. This is supported by the research of Yudianti (2005); Wardani and Siregar (2009) and Arieska and Gunawan (2011) whereby dividends are able to moderate over free cash flow towards firm value. The research conducted by Erlangga and Suryandari (2009); Martini (2014); Setiawan and Riduwan (2015) and Rochmah and Fitria (2017) show that the influence of profitability on firm value can be moderated by dividend. In accordance with the Signaling Theory, dividend payments can give 


\section{NATVNALYY ACCREDTEO JOURNAL - DECREE NO. 21/E/KPV/2O18}

a signal about the condition of the company, where the higher the dividend given, the higher the value of the firm, and hereby increase the shareholders' wealth.

Based on the background above, this study tries to investigate the moderation effect of Dividend Policy (Dividend Payout Ratio-DPR) on Free Cash Flow (FCF) and Profitability (Return on Asset - ROA) towards Firm Value (Price to Book Value). Manufacturing companies are used as population and research samples because they have average free cash flow and profitability above the average of the other industrial sectors, as well as the most number of companies that provide dividends. The analytical tool used to see this moderation effect is Moderated Regression Analysis (MRA).

\section{THEORETICAL FRAMEWORK AND HYPOTHESES DEVELOPMENT}

\section{A. Literature Review}

\section{Agency Theory}

Jensen and Meckling (1976) revealed that agency theory explains the relationship between agent (manager) and principal (shareholder). The relationship between the agent and the principal is usually in the asymmetric information situation, where the agent has more information than the principal because the manager did the operational welfare. On the other hand, shareholders want the manager to work for the welfare of the shareholders but the company managers can act the other way. Due to the emergence of such a conflict of interest, shareholders must issue a number of costs called agency costs to exercise total supervision of the managers.

\section{Signaling Theory}

Signaling Theory is an action taken by the management of the company to provide guidance or information for investors concerning how management views the prospects of the company (Atmaja, 2008). The company is pushed to provide information because there is an asymmetric information between the company and the outside parties (especially investors and creditors). This theory states that investors can distinguish between companies that have high value with companies that have low value. Companies that always generate profits will give a positive signal compared to companies that are less profitable.

\section{Dividend Irrelevance Theory}

According to Modigliani and Miller (MM), the value of the company is not determined by the amount of the dividend distribution but is determined by the net profit before tax and the risk class of the company. This MM statement is based on several important assumptions such as (Brigham and Houston, 2006):

a) The perfect capital market where all investors are rational

b) No new share issuance costs if the company issues new shares

c) No taxes

d) The company's investment policy has not changed

\section{Bird in The Hand Theory}

This theory is proposed by Gordon and Lintner which states that dividend policy has a positive effect on stock market prices. That is, the greater the dividend distributed by 
the company, the higher the stock market price of the company so as to affect the increase of company value. Gordon and Lintner argue that the capital cost of shares will decline as dividend payouts are raised as investors are less confident of capital gains that will result from retained earnings than dividends received (Brigham and Houston, 2006).

B. Conceptual Framework

In this study, there are three kinds of variables: dependent variable, independent variable, and moderation variable. The dependent variable is the Firm Value proxies by Price to Book Value (PBV). Independent variables are Free Cash Flow (FCF) and Profitability proxies by Return on Assets (ROA). The moderation variable is Dividend Policy proxies by Dividend Payout Ratio (DPR). The conceptual framework of this study can be seen as follows:

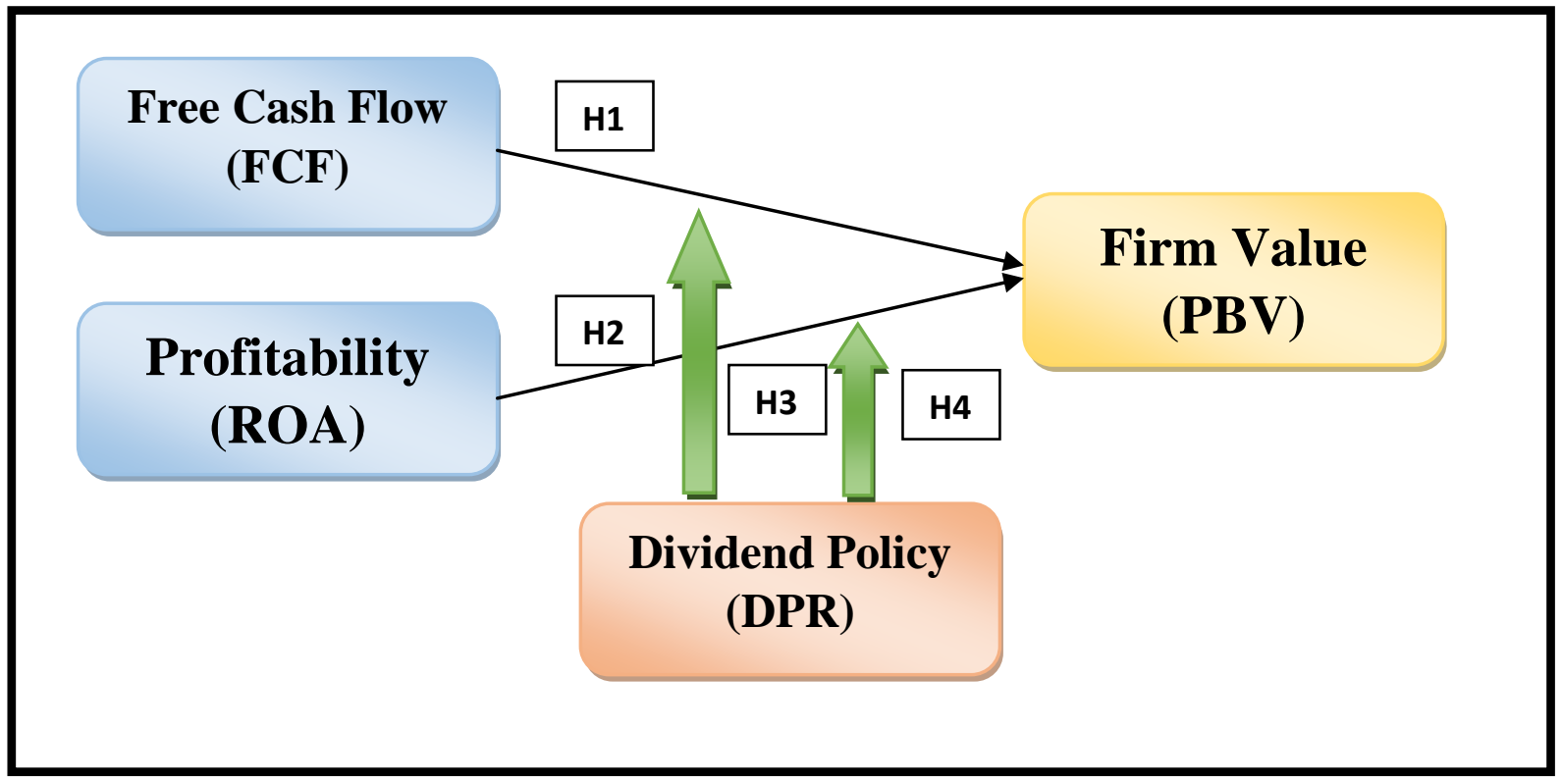

Diagram 1: Conceptual Framework

\section{Hypotheses Development}

1. Effect of Free Cash Flow Towards Firm Value

Free cash flow is the sum of the surplus funds after funding profitable projects (Jensen, 1986). High free cash flow will provide flexibility for managers to make additional investment for the company so that it can boost firm performance. High firm performance positively signals the future prospects of the company so as to increase shareholder value and ultimately help increase the value of the firm. This statement is supported by studies conducted by Suartawan and Yasa (2016), Sindhu (2014), and Andini and Wirawati (2014). Therefore, it can be drawn that the first hypothesis of this research is: 


\section{NATONALY ACCREDTEO JOURNAL - DECREE NO. 21/E/KPT/2O18}

H1: Free Cash Flow has positive effect on Firm Value

\section{Effect of Profitability Towards Firm Value}

The higher the profitability, the available profit to be distributed to shareholders also becomes greater. This will signal to the public that the company is not easy to go bankruptcy so that the value of the firm will increase. Increased ROA indicates an improved corporate prospect, which will be considered as a positive signal by investors which further facilitates the management of the company to attract capital in the form of shares. If there is an increase in demand for shares, it will raise the stock price in the capital market (assuming ceteris paribus). Researches by Chen and Chen (2011) and Hendrayana and Yasa (2016) proved that profitability has a positive effect on firm value. Therefore, it can be drawn that the second hypothesis of this research is:

H2: Profitability has positive effect on Firm Value

3. Moderating Effect of Dividend Policy on Free Cash Flow Towards Firm Value

An agency problem arises when managers (agent) own only small percentage of the stock compare to shareholders (principal). Therefore, shareholder wealth maximization could take a back seat to managers' personal goals (Brigham and Daves, 2004). A large number of free cash flow that generated by company can rise conflict of interest between shareholders and managers. Thereby dividend payout policy can play important role to overcome this problem. Cash dividend could reduce agency problems between shareholders and managers by reducing amount of free cash flow that might otherwise be invested in low return projects. The increase of dividend in cash will cause good impact on stock price. The higher the stock price the higher the wealth of shareholders (Jensen, 1976, 1986). Firm value is an important concept to investors because it related to the wealth of shareholders. Yudianti (2005) divided free cash flow into positive free cash flow and negative free cash flow. Positive free cash flow can be used as a determinant of shareholder value by considering dividend as contextual factor, conversely the negative free cash flow sample shows that the result is statistically insignificant. In most cases, positive free cash flow is considered by external financial reporting users as a value that describes the achievement of management in managing the company. Unfortunately, external users could not differentiate the information content of negative free cash flow which is caused by exploitation of unprofitable investment or information content of negative free cash flow caused by investment in a growth company. In addition, Wardani and Siregar (2009) reported that the influence of free cash flow on shareholder value is moderated by dividend. This finding supported by Arieska and Gunawan (2011) that studied manufacture firms which were listed in Indonesian Stock Exchange in the period 2005 - 2009. Therefore, it can be drawn that the third hypothesis of this research is:

H3: Dividend Policy has a significant moderating effect on Free Cash Flow towards Firm Value 


\section{NATVNALY ACCCREDTEO JOURNAL - DECREE NO. 21/E/KPV/2O18}

\section{Moderating Effect of Dividend Policy on Profitability Towards Firm Value}

Firm value is shown by the firm ability to pay dividends. The amount of dividends paid may affect the stock price. The firm ability to pay dividends is closely related to the firm ability to make profit. If the firm generates high profit, then the firm will be able to pay high dividend. A high dividend will be a good signal to investors; therefore, the value of the firm will increase. Whereas if the proportion or payout profit is too high, it will reduce to the investment's ability of the firm that might give a good return in the future. In this case, the firm value will decrease (Martini, 2014). Rochmah and Fitria (2017) found that the effect of profitability on firm value can be moderated by dividend policy. It is consistent with research findings of Setiawan and Riduwan (2015), Martini (2014), and Erlangga and Suryandari (2009). Therefore, it can be drawn that the fourth hypothesis of this research is:

H4: Dividend Policy has a significant moderating effect on Profitability towards Firm Value

\section{RESEARCH METHOD AND DATA DESCRIPTION}

\section{Research Method}

This study is an associative research, with Firm Value as the dependent variable proxies by Price to Book Value (PBV), independent variables: Free Cash Flow (FCF) and Profitability (Return On Asset - ROA), and Dividend Payout Ratio (DPR) as the moderating variable. Data collection method used is Sample Survey using population of all manufacturing companies listed on Indonesia Stock Exchange (BEI) during period of 2010 to 2015 as many as 145 companies. Sampling method used is purposive sampling method. Selection criteria are: a company listed on the IDX, has complete financial reports in Rupiah currency, and routine dividend payout during the period of research. We obtained 17 companies as our research sample in accordance with the criteria above and merge the sample by using panel data (combination between time-series and cross-section data).

We use Moderated Regression Analyze (MRA) to calculate the equations proposed. As stated by Ghozali (2012), the test against the effects of moderations can be done in two ways as follows:

a) Moderating effect seen from increase of $\mathrm{R}^{2}$ regression equation containing with the main effects and moderation effects of the regression equations contained only with the main effect alone.

b) moderating effects can also be seen from the significance of $\beta_{3}$ coefficients of the interaction (VI * VMO).

\section{Data Descriptions}

a) Dependent variable is Firm Value which is proxies by Price to Book Value $(\mathrm{PBV})$. Price to Book Value (PBV) is the ratio of the stock price to the book value per share expressed in ratio. 


$$
\mathrm{PBV}=\frac{\text { Price per share }}{\text { Book Value per share }}
$$

b) Independent variable is Free Cash Flow (FCF) and Profitability (ROA).

1. Free Cash Flow (FCF) is cash from operations available to be distributed to investors including shareholders, creditors and preferred stocks. FCF is expressed by ratio such as quote from Mardasari (2014). Ratio of FCF can be calculated as below:

$$
\text { FCF }=\frac{\text { NOPAT }+ \text { Depreciation }- \text { Gross fixed asset expenditures }-\Delta \text { NOWC }}{\text { Total Asset }} \times 100 \%
$$

$$
\begin{array}{ll}
\text { FCF } & =\text { Free Cash Flow } \\
\text { NOPAT } & =\text { Net Operating Profit after Tax } \\
\Delta \text { NOWC } & =\text { Change in Net Operating Working Capital }
\end{array}
$$

2. Profitability is proxies by Return on Assets (ROA), is a ratio of earnings before tax with total assets.

$$
\mathrm{ROA}=\frac{\text { Earnings before Tax }}{\text { Total Assets }} \times 100 \%
$$

c) Moderating variable is Dividend Payout Ratio (DPR), is related to profit sharing to shareholders whether the profit generated by the company that will be used to distribute dividend to shareholders or made as retained earnings. DPR can be calculated by divided dividend per share to earnings per share.

$$
\mathrm{DPR}=\frac{\text { Dividend per Share }}{\text { Earnings per Share }} \times 100 \%
$$

\section{ECONOMETRIC MODEL}

1. Effect of Free Cash Flow towards Firm Value

$\mathrm{PBV}_{\mathrm{it}}=\alpha+\beta_{1} \mathrm{FCF}_{\mathrm{it}}+\mathrm{e}_{\mathrm{it}}$

2. Effect of Profitability towards Firm Value

$\mathrm{PBV}_{\text {it }}=\alpha+\beta_{1} \mathrm{ROA}_{i t}+\mathrm{e}_{\mathrm{it}}$

3. Moderating Effect of Dividend Policy on Free Cash Flow towards Firm Value $\mathrm{PBV}_{\text {it }}=\alpha+\beta_{1} \mathrm{FCF}_{\text {it }}+\beta_{2} \mathrm{DPR}_{\mathrm{it}}+\beta_{3} \mathrm{FCF}_{\mathrm{it}}{ }^{*} \mathrm{DPR}_{\mathrm{it}}+\mathrm{e}_{\mathrm{it}}$

4. Moderating Effect of Dividend Policy on Profitability towards Firm Value $\mathrm{PBV}_{\mathrm{it}}=\alpha+\beta_{1} \mathrm{ROA}_{\mathrm{it}}+\beta_{2} \mathrm{DPR}_{\mathrm{it}}+\beta_{3} \mathrm{ROA}_{\mathrm{it}}{ }^{*} \mathrm{DPR}_{\mathrm{it}}+\mathrm{e}_{\mathrm{it}}$ 
NATONALY ACCREDTEO JOURNAL - DECREE NO. 21/E/KPV/2018

\section{EMPIRICAL RESULT AND DISCUSSION}

1. Effect of Free Cash Flow towards Firm Value

Table 1. Result of regression analysis model 1

\begin{tabular}{ccccc}
\hline Variable & Coefficients & $\begin{array}{c}\mathrm{p} \text {-value } \\
(\text { sig. })\end{array}$ & $\mathrm{t}$ - value & $\begin{array}{c}\mathrm{R}^{2} \\
(\text { Adjusted } \\
\left.\mathrm{R}^{2}\right)\end{array}$ \\
\hline Intercept & 0.673 & & & 0.200 \\
Free Cash Flow & 0.290 & $0.000^{*}$ & 4.000 & $(0.187)$
\end{tabular}

Source: SPSS output

Note: * denote significant at $5 \%$ levels

$\mathrm{LnPBV}_{\text {it }}=0.673+0.290 \mathrm{LnFCF}_{\text {it }}$

Interpretation of the estimated model 1

Free cash flow which in this case is represented by LnFCF have a coefficient value of +0.290 , and is found to be statistically significant ( $\mathrm{t}$-stats $=4.000, \mathrm{p}$-value $=0.000$ ) although the model has just explained $20 \%$ of variance in the dependent variable (LnPBV). The result indicated that Free Cash Flow (FCF) has a positive significant effect towards Firm Value (PBV) which is consistent with prior researches by Suartawan and Yasa (2016), Sindhu (2014), and Andini and Wirawati (2014). High free cash flow can positively signal the future prospects of the company so as to increase shareholder value and ultimately help to increase the value of the firm.

2. Effect of Profitability towards Firm Value

Table 2. Result of regression analysis model 2

\begin{tabular}{ccccc}
\hline Variable & Coefficients & $\begin{array}{c}\mathrm{p} \text {-value } \\
(\text { sig. })\end{array}$ & $\mathrm{t}$-value & $\begin{array}{c}\mathrm{R}^{2} \\
(\text { Adjusted } \\
\left.\mathrm{R}^{2}\right)\end{array}$ \\
\hline Intercept & -1.272 & & & 0.543 \\
Profitability & 0.936 & $0.000^{*}$ & 8.717 & $(0.536)$
\end{tabular}

Source: SPSS output

Note: * denote significant at $5 \%$ levels

$\mathrm{LnPBV}_{\text {it }}=-1.272+0.936 \mathrm{LnROA}_{\mathrm{it}}$

Interpretation of the estimated model 2

Profitability which in this case is represented by LnROA have a coefficient value of +0.936 , and is found to be statistically significant ( $\mathrm{t}$-stats $=8.717$, p-value $=0.000$ ) although the model has just explained $54.3 \%$ of variance in the dependent variable 
(LnPBV). The result indicated that Profitability (ROA) has a positive significant effect towards Firm Value (PBV) which is consistent with prior researches by Chen and Chen (2011) and Hendrayana and Yasa (2015). The higher the profitability, the available profit to be distributed to shareholders also becomes greater. This will signal to the public that the company is not easy to go bankruptcy so that the value of the firm will increase.

\section{Moderating Effect of Dividend Policy on Free Cash Flow towards Firm Value}

Table 3. Result of moderated regression analysis (model 3)

\begin{tabular}{ccccc}
\hline Variable & Coefficients & $\begin{array}{c}\mathrm{p}-\text { value } \\
(\text { sig. })\end{array}$ & $\mathrm{t}$ - value & $\begin{array}{c}\mathrm{R}^{2} \\
(\text { Adjusted } \\
\left.\mathrm{R}^{2}\right)\end{array}$ \\
\hline Intercept & -0.241 & 0.852 & -0.187 & \\
Free Cash Flow & -0.133 & 0.783 & -0.277 & 0.353 \\
Dividend Policy & 0.259 & 0.455 & 0.752 & $(0.322)$ \\
Moderat1 & 0.104 & 0.412 & 0.826 & \\
\hline
\end{tabular}

Source: SPSS output

$\mathrm{LnPBV}_{\mathrm{it}}=-0.241-0.331 \mathrm{LnFCF}_{\mathrm{it}}+0.259 \mathrm{LnDPR}_{\mathrm{it}}+0.104 \mathrm{LnFCF}_{\mathrm{it}}{ }^{*} \mathrm{LnDPR}_{\mathrm{it}}$

\section{Interpretation of the estimated model 3}

The moderating variable (Dividend Policy) in this equation which in this case is represented by $\mathrm{LnFCF}^{*} \mathrm{LnDPR}$ have a coefficient value of +0.104 , is found to be statistically insignificant ( $\mathrm{t}$-stats $=0.826, \mathrm{p}$-value $=0.412$ ) although all independent variables in the model has explained $35.3 \%$ of variance in the dependent variable (LnPBV). Even though at the first model the FCF is significantly effects Firm Value, but in this equation DPR is just a potential moderating variable. Here, DPR is only affecting the potential relationship but not interacting with the predictor (FCF) and the dependent variable $(\mathrm{Y})$. This result is supported by Dividend Irrelevance Theory by Modigliani and Miller (MM) where the value of the company is not determined by the amount of the dividend distributed but is determined by the net profit before tax and the risk class of the company. 
NATONALY ACCREDTEO JOURNAL - DECREE NO. 21/E/KPV/2018

\section{Moderating Effect of Dividend Policy on Profitability towards Firm Value}

Table 4. Result of moderated regression analysis (model 4)

\begin{tabular}{ccccc}
\hline Variable & Coefficients & $\begin{array}{c}\mathrm{p}-\text { value } \\
(\mathrm{sig} .)\end{array}$ & $\mathrm{t}$ - value & $\begin{array}{c}\mathrm{R}^{2} \\
(\text { Adjusted } \\
\left.\mathrm{R}^{2}\right)\end{array}$ \\
\hline Intercept & -0.486 & 0.824 & -0.223 & \\
Profitability & 0.176 & 0.810 & 0.241 & 0.624 \\
Dividend Policy & -0.144 & 0.802 & -0.252 & $(0.606)$ \\
Moderat2 & 0.177 & 0.352 & 0.938 & \\
\hline
\end{tabular}

Source: SPSS output

$\mathrm{LnPBV}_{i t}=-0.486+0.176 \mathrm{LnROA}_{\mathrm{it}}-0.144 \mathrm{LnDPR}_{\mathrm{it}}+0.177 \mathrm{LnROA}_{\mathrm{it}}{ }^{*} \mathrm{LnDPR}_{\mathrm{it}}$

\section{Interpretation of the estimated model 4}

The moderating variable (Dividend Policy) in this equation which in this case is represented by $\mathrm{LnROA}^{*} \mathrm{LnDPR}$ have a coefficient value of +0.177 , is found to be statistically insignificant ( $\mathrm{t}$-stats $=0.938, \mathrm{p}$-value $=0.352$ ) although all independent variables in the model has explained $62.4 \%$ of variance in the dependent variable (LnPBV). Even though at the first model the ROA is significantly effects Firm Value, but in this equation DPR is just a potential moderating variable. Here, DPR is only affecting the potential relationship but not interacting with the predictor (ROA) and the dependent variable (PBV).

\section{CONCLUSION AND FURTHER STUDY}

This study examines whether Free Cash Flow and Profitability could influence Firm Value and in case this model can be moderated by Dividend Policy. As predicted, each Free Cash Flow and Profitability has positive significant effect toward Firm Value. These findings indicate that high Free Cash Flow and profitability are considered as positive signal by investors that will increase the value of the firm. Otherwise, Free Cash Flow and Profitability does not have significant effect on Firm Value after being moderated by Dividend Policy. It is because the direct effect of Free Cash Flow and Profitability toward Firm value is bigger than the indirect effect.

The limitation of this study relates to the unit of sample because the number of company which had distributed cash dividend regularly for six consecutive years (2010 - 2015) is relatively small, only 17 firms. In order to increase the number of observation, we use panel data. Thus, further study may analyze all firms listed on Indonesian Stock Exchange and consider other factors that might affect Firm value. 


\section{NATVNALYY ACCREDTEO JOURNAL - DECREE NO. 21/E/KPV/2O18}

\section{REFERENCES}

Andini, Ni Wayan Lady and Wirawati, Ni Gusti Putu. 2014. Pengaruh Cash Flow Pada Kinerja Keuangan Dan Implikasinya Pada Nilai Perusahaan Manufaktur. Jurnal Akuntansi Universitas Udayana, 7(1), 107-121.

Arieska, Metha and Barbara Gunawan. 2011. Pengaruh Aliran Kas Bebas dan Keputusan Pendanaan Terhadap Nilai Pemegang Saham dengan Set Kesempatan Investasi dan Dividen sebagai Variabel Moderasi. Jurnal Akuntansi dan Keuangan, 13(1), 12-23.

Atmaja, Lukas Setia. (2008). Teori dan Praktik Manajemen Keuangan. Yogyakarta: Penerbit ANDI. Brigham, Eugene F dan Philip R. Daves. (2004) Intermediate Financial Management - International Student Edition (8th ed). USA: Thomson South-Western.

Brigham, Eugene F. dan Houston, Joel F. 2006. Fundamentals of Financial Management (10th ed.book 1). Jakarta: Salemba Empat.

Chen, L. J., \& Chen, S. Y. (2011). The Influence of Profitability on Firm Value with Capital Structure as The Mediator and Firm Size and Industry as Moderators. Investment Management and Financial Innovations , 8(3), 121-129.

Erlangga, Enggar and Suryandari, Erni. 2009. Pengaruh Kinerja Keuangan terhadap Nilai Perusahaan Dengan Pengungkapan CSR, Good Corporate Governance dan Kebijakan Dividen Sebagai Variabel Pemoderasi. Jurnal Akuntansi \& Investasi, 10(1), 57-70.

Ghozali, Imam. (2012). Aplikasi Analisis Multivariate Dengan Program IBM SPSS 20 (6 ${ }^{\text {th }}$ ed.). Semarang: Badan Penerbit Universitas Diponegoro.

Harjito, Agus and Martono. (2005). Manajemen Keuangan (2nd ed.). Yogyakarta: Penerbit Ekonisia.

Hendrayana, P. W., \& Yasa, G. W. (2015). Pengaruh Komponen RGEC Pada Perubahan Harga Saham Perusahaan Perbankan di Bursa Efek Indonesia. E-Jurnal Akuntansi Universitas Udayana, 11(1), 74 - 89.

Husnan, Suad and Enny Pudjiastuti. (2012). Dasar - Dasar Manajemen Keuangan (6 ${ }^{\text {th }}$ ed.). Yogyakarta. UPP STIM YKPN

Jensen, M. \& Meckling, W. 1976. Theory of The Firm: Managerial Behavior, Agency Costs, and Ownership Structure. Journal of Financial Economics, 3(4), 305-360.

Jensen, M. C. 1986. Agency Costs of Free Cash Flow, Corporate Finance, and Takeover. American Economic Review, 76, 323-339.

Mardasari, Rizky Budi. (2014) Pengaruh Insider Ownership, Kebijakan Hutang Dan Free Cash Flow Terhadap Nilai Perusahaan Melalui Kebijakan Dividen. Jurnal Ilmu Manajemen, 2(4), $1807-1820$.

Martini, Putri Dwi and Riharjo,Ikhsan Budi. 2014. Pengaruh Kebijakan Utang Dan Profitabilitas Terhadap Nilai Perusahaan: Kebijakan Dividen Sebagai Variabel Pemoderasi. Jurnal Ilmu dan Riset Akuntansi, 3(2), 1-16.

Rochmah, Siti Ainur and Fitria, Astri. 2017. Pengaruh Kinerja Keuangan Terhadap Nilai Perusahaan: Kebijakan Dividen Sebagai Variabel Moderating. Jurnal Ilmu dan Riset Akuntansi, 6(3), 998-1017.

Sartono, Agus. (2001). Manajemen Keuangan: Teori dan Aplikasi (4th ed.). Yogyakarta: BPFE. 
Setiawan, Firman and Riduwan, Akhmad. 2015. Pengaruh ROA, Ukuran Perusahaan Pada Nilai Perusahaan: DPR Sebagai Variabel Pemoderasi. Jurnal Ilmu dan Riset Akuntansi, 4(8), 1-17.

Sindhu, Muzammal Ilyas. 2014. Relationship between free cash flow and dividend: Moderating role of firm size. Research Journal of Finance and Accounting, 5(5): 16-23.

Suartawan, I G. N. Putu Adi and Yasa, Gerinta Wirawan.(2016). Pengaruh Invesmen Opportunity Set Dan Free Cash Flow Pada Kebijakan Dividend dan Nilai Perusahaan. EJurnal Akuntansi Universitas Udayana , 14(3), 2014 - 2044.

Wardani, R.A.Kusuma and Siregar, Baldric, (2009) Pengaruh Aliran Kas Bebas Terhadap Nilai Pemegang Saham Dengan Set Kesempatan Investasi dan Dividen Sebagai Variabel Moderator. Jurnal Akuntansi dan Manajemen. 20(3), 157-174.

Yudianti, Fr. Ninik. 2005. Analisis pengaruh set kesempatan investasi, manajemen laba, leverage dan dividen terhadap hubungan antara aliran kas bebas dan nilai pemegang saham. Disertasi, Gajah Mada University Yogyakarta. http://repository.wima.ac.id/6536 